\title{
Duchenne muscular dystrophy with adrenal insufficiency and glycerol kinase deficiency: high resolution cytogenetic analysis with molecular, biochemical, and clinical studies
}

\author{
A CLARKE*, S H ROBERTS + , N S T THOMAS*, A WHITFIELD , \\ J WILLIAMS $\S$, AND P S HARPER*
}

From * the Section of Medical Genetics, and \$the Department of Medical Biochemistry, University of Wales College of Medicine, Cardiff; the Regional Cytogenetics Unit, University Hospital of Wales, Cardiff; and $\Varangle$ the Department of Clinical Biochemistry, Institute of Child Health, London.

SUMMARY A syndrome of Duchenne muscular dystrophy (DMD), adrenal hypoplasia, glycerol kinase deficiency, and mental retardation has been recognised. We report a further case ascertained from a history of DMD, severe mental retardation, and an Addison-like disorder.

Cytogenetic analysis of the proband revealed an interstitial deletion of the short arm of the $\mathrm{X}$ chromosome, from Xp21.1 to Xp22.11, comprising about $9 \%$ of the length of the normal X chromosome. His mother was heterozygous for the deletion, but his maternal grandmother and sister both had two normal X chromosomes. DNA probe analysis confirmed the existence of a deletion in the affected boy, as probes $754, \mathrm{C} 7, \mathrm{XJ} 1-1$, and pERT87 consistently failed to hybridise to his DNA. His sister was heterozygous for the RFLP associated with 754, thus confirming that she had two normal $\mathrm{X}$ chromosomes.

There was no evidence of chronic granulomatous disease, other immunological defect, or retinitis pigmentosa in this case. Biochemical studies revealed gross glyceroluria and hyperglycerolaemia, indicating glycerol kinase deficiency which has been confirmed enzymatically. We have subsequently screened 21 other boys with DMD for glyceroluria and found one other case.

Cytogenetic analysis has also been performed in nine other families, where a boy with DMD has been shown to have a deletion of DNA sequences localised to the region Xp21. None of these cases demonstrated any cytogenetic abnormality, nor has their clinical course been unusual.

The syndrome of Duchenne muscular dystrophy (DMD), adrenal hypoplasia (AH), mental retardation (MR), and glycerol kinase (GK) deficiency has been recognised for several years. ${ }^{1}$ Several of these boys have been found to carry interstitial deletions of the short arm of the $\mathrm{X}$ chromosome $\mathrm{e}^{2-4}$ and two similar cases have been described where there is a molecular deletion that has not been shown cytogenetically. ${ }^{45}$ One boy with the same clinical features has also been reported, who has neither a cytogenetic nor a molecular deletion. ${ }^{5}$

A boy with DMD, mental retardation, and an interstitial deletion of $\mathrm{Xp} 21$ has been identified, who is not known to have any additional pathology or

Received for publication 3 July 1986.

Revised version accepted for publication 5 August 1986. biochemical anomaly, ${ }^{\circ}$ while a family where $\mathrm{X}$ linked $\mathrm{AH}$ is associated with GK deficiency, but not with myopathy, has been found to carry an interstitial deletion of $\mathrm{Xp} 21 \cdot 2 .{ }^{7}$ The evidence suggests that the gene loci for $\mathrm{AH}$ and GK deficiency map distal to the DMD locus, within band Xp21.2-3.

A woman has been described with a deletion of $\mathrm{Xp12}$ to Xp21 on one of her X chromosomes, whose son died at the age of 36 hours, and is known to have had GK deficiency, $\mathrm{AH}$, and ornithine transcarbamylase (OTC) deficiency. ${ }^{8} \mathrm{~A}$ single case with DMD, chronic granulomatous disease (CGD), McLeod red cell phenotype, and possible retinitis pigmentosa has been reported, in which there is also a cytogenetic deletion of $\mathrm{Xp} 21 .{ }^{9}$

We report here an additional case of DMD with an interstitial deletion of the short arm of the $X$ 
TABLE 1 Males with interstitial deletions of Xp21.

\begin{tabular}{|c|c|c|c|c|c|c|c|c|c|c|c|c|}
\hline & $\begin{array}{l}\text { Bartley } \\
\text { et } a l^{2}\end{array}$ & $\begin{array}{l}\text { Patil } \\
\text { et } \text { al }^{7}\end{array}$ & $\begin{array}{l}\text { Patil } \\
\text { et } a l^{7}\end{array}$ & $\begin{array}{l}\text { Saito } \\
\text { et } \text { al }^{3}\end{array}$ & $\begin{array}{l}\text { Wieringa } \\
\text { et } a l^{4}\end{array}$ & $\begin{array}{l}\text { Wieringa } \\
\text { et } a l^{4}\end{array}$ & $\begin{array}{l}\text { Dunger } \\
\text { et al }\end{array}$ & $\begin{array}{l}\text { Wilcox } \\
\text { et } a l^{\circ}\end{array}$ & $\begin{array}{l}\text { Hammond } \\
\text { et al }\end{array}$ & $\begin{array}{l}\text { Francke } \\
\text { et al }\end{array}$ & $\begin{array}{l}\text { Franke } \\
\text { et al }\end{array}$ & $\begin{array}{l}\text { This } \\
\text { report }\end{array}$ \\
\hline Identification & III. 3 & Family 1 & Family 2 & & $\begin{array}{l}\text { Family } 1 \\
\text { (as described } \\
\text { in ref } 11 \text { ) }\end{array}$ & Family 2 & Patient 1 & $\begin{array}{l}\text { SS } \\
\text { and } \\
\text { JD }\end{array}$ & & BB & $\begin{array}{l}\mathrm{KC} \\
\text { (female) }\end{array}$ & Case 1 \\
\hline Myopathy & + & + & & + & + & + & + & + & & + & & + \\
\hline GK deficiency & + & + & + & + & + & + & + & & + & + & & + \\
\hline $\begin{array}{l}\text { AH } \\
\text { Mental }\end{array}$ & + & + & + & + & + & + & + & & + & + & & + \\
\hline retardation & + & + & + & + & + & + & + & $\begin{array}{l}\text { SS + } \\
\text { JD - }\end{array}$ & & + & + & + \\
\hline OTC deficiency & & & & & & & & & + & & + & - \\
\hline CGD & & & & & & & & - & & + & + & - \\
\hline $\begin{array}{c}\text { DNA probe } \\
\text { deletion }\end{array}$ & & 754 & & & 754 & 754 & $\begin{array}{l}\text { C7 } \\
754 \\
\text { OTC }\end{array}$ & $\begin{array}{l}\text { pERT87 } \\
754\end{array}$ & & $\begin{array}{l}\text { pERT87 } \\
754\end{array}$ & & $\begin{array}{l}\text { C7 } \\
\text { pERT87 } \\
\text { XJ1-1 } \\
754\end{array}$ \\
\hline $\begin{array}{l}\text { Flanking DNA } \\
\text { probes not } \\
\text { deleted }\end{array}$ & & OTC & $\begin{array}{l}\text { OTC } \\
754\end{array}$ & & $\begin{array}{l}\text { OTC } \\
\mathrm{C} 7\end{array}$ & $\begin{array}{l}\mathbf{L} 1 \cdot 28 \\
\mathrm{C} 7\end{array}$ & & $\begin{array}{l}\text { OTC } \\
\mathrm{C} 7\end{array}$ & $\begin{array}{l}\text { OTC } \\
\text { C7 }\end{array}$ & & & $\begin{array}{l}\text { OTC } \\
99 \cdot 6\end{array}$ \\
\hline $\begin{array}{c}\text { Cytogenetic } \\
\text { deletion }\end{array}$ & $\begin{array}{l}\mathrm{Xp} 21 \cdot 2 \\
\mathrm{Xp}_{21 \cdot 3}\end{array}$ & $\begin{array}{l}\mathrm{Xp} 21 \cdot 2 \\
\overrightarrow{X p 21 \cdot 3}\end{array}$ & $\mathrm{Xp} 21 \cdot 2$ & $\mathrm{Xp} 21$ & $\mathrm{Xp} 21 \cdot 2$ & & & $\begin{array}{l}\mathrm{Xp} 21 \cdot 1 \rightarrow \\
\mathrm{Xp} 21 \cdot 3 \\
\text { confirmed } \\
\text { on flow } \\
\text { cytometry }\end{array}$ & $\begin{array}{l}\text { Xp11·2 } \\
\text { Xp21 } \\
\text { inferred } \\
\text { from } \\
\text { mother's } \\
\text { karyotype }\end{array}$ & $\begin{array}{l}\text { Xp21.1 } \\
\pm \text { parts of } \\
\text { Xp21.2 } \\
\text { and/or } \\
\text { Xp21.3 }\end{array}$ & $\begin{array}{l}\mathrm{Xp} 21 \cdot 1 \\
\mathrm{Xp}_{21 \cdot 3}\end{array}$ & $\begin{array}{l}\mathrm{Xp} 21 \cdot 1 \\
\mathrm{Xp}_{22} \cdot 11\end{array}$ \\
\hline
\end{tabular}

chromosome: he has GK deficiency, $\mathrm{AH}$, and mental retardation. We also report cytogenetic and biochemical studies performed on other boys with DMD, one of whom exhibits glyceroluria.

The findings in the new case and the previously reported cases of $\mathrm{Xp}$ interstitial deletion are summarised in table 1.

\section{Case report}

The family of case 1 came to our attention because his sister $(\mathrm{KH})$ was pregnant and requested prenatal diagnosis. Her brother (case 1) is an 18 year old male with DMD and mental retardation. Congenital adrenal hypoplasia was diagnosed in the neonatal period, since when he has required mineralocorticoid therapy. A three day Synacthen test performed at the age of 2 years demonstrated the continued need for this therapy.

His development was delayed, and he could neither walk nor talk until the age of 3 years. He required education in a special school. This boy's growth has also been impaired, and he was below the 3rd centile for height and weight at the age of 9 years.

Duchenne muscular dystrophy was diagnosed at the age of 9 from the typical distribution of proximal myopathy and raised serum creatine kinase $(>5500$ IU/l). This condition has progressed and he has been wheelchair bound since $10^{1 / 2}$ years, with widespread muscle contractures and a severe kyphoscoliosis. He has also been subject to recurrent chest infections and there has been ECG evidence of mild cardiac involvement, with inverted $\mathrm{T}$ waves in lead $\mathrm{V} 3$ since 8 the age of 10 . Muscle biopsy was performed at 180 years of age, but yielded adipose tissue with insufficient muscle to permit a histological diag-? nosis.

This boy's delayed mental and motor development prevented his attending a normal school. He has not recently had a formal IQ assessment, but he functions at an IQ level of about 60 . He is unable to read or write, but manages to concentrate for long enough at times to perform useful handicraft at an adult training centre.

At the time of referral of his sister, the possibility that the patient might represent a deletion syndrome was recognised. This prompted urgent clinical and laboratory investigations: in particular, glyceroluria was sought because of the clinical resemblance to published cases of GK deficiency, and family studies involving cytogenetic and DNA probe analysis were pursued simultaneously.

The possibility that our patient might manifest some of the other $\mathrm{X}$ linked diseases found in the patient of Francke et al has been investigated and excluded (table 2). He has normal leucocyte function (in particular, no evidence of chronic granulomatous disease), normal immunoglobulins, a normal erythrocytic phenotype, and no orotic acid in his urine (making OTC deficiency unlikely). The patient is myopic, but there is no clinical evidence of retinitis pigmentosa or other ocular pathology at 18 years of age. The finding of normal serum calcium 
TABLE 2 Investigations of patient for possible $X$ linked disorders.

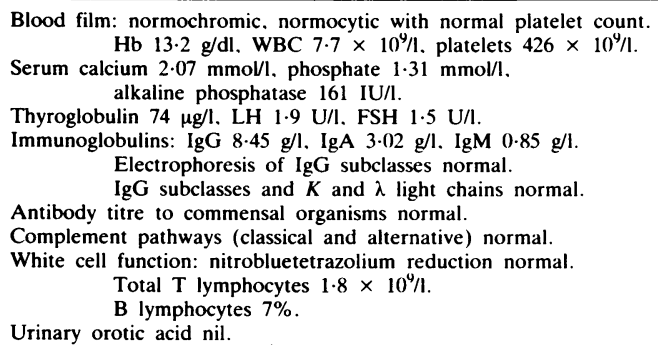

and phosphate levels, together with the absence of clinical features of familial hypophosphataemia, is of interest in view of the recent localisation of this gene to $\mathrm{Xp} 22 .^{12}$

\section{Methods}

CYTOGENETIC ANALYSIS

Heparinised peripheral blood was cultured in McCoy's 5A medium supplemented with $20 \%$ fetal calf serum using standard techniques. The synchrony of cell division required for high resolution banding studies was induced by the addition of excess thymidine (final concentration $0.3 \mathrm{mg} / \mathrm{ml}$ ) at 48 hours. ${ }^{13}$ The thymidine block was released at 65 hours by centrifugation and resuspension of the cells in fresh medium, or by the addition of deoxycitidine (method to be published elsewhere). At 70 hours, after a 15 minute exposure to colcemid $(0 \cdot 1 \mu \mathrm{g} / \mathrm{ml})$, the cells were centrifuged for 10 minutes and resuspended in hypotonic $\mathrm{KCl}$ solution $(0.05 \mathrm{~mol} / \mathrm{l})$ for 10 minutes. Fixation in methanol/acetic acid was in accordance with conventional procedures. Spreading of the chromosomes was achieved by the addition of drops of the fixed cell suspension to cold, wet slides which were air dried on a warm plate. The slide preparations were pretreated with $\mathrm{H}_{2} \mathrm{O}_{2}$ and GTG banded with a method modified from that of Seabright. ${ }^{14}$ Late replication studies were performed using a modification of the method of Perry and Wolff, ${ }^{15}$ whereby BrdU (final concentration 100 $\mu \mathrm{g} / \mathrm{ml}$ ) was added for the final seven hours of a standard 72 hour lymphocyte culture. The slides were stained in Hoechst $33258(10 \mu \mathrm{g} / \mathrm{ml}$ deionised water), exposed to ultraviolet light for 90 minutes, and incubated in $2 \times \mathrm{SSC}$ at $60^{\circ} \mathrm{C}$ for 30 minutes before staining in $10 \%$ Giemsa.

DNA ANALYSIS

Samples of blood were taken from family members and stored at $-20^{\circ} \mathrm{C}$. Total genomic DNA was extracted by the method of Kunkel et al. ${ }^{16}$ DNA samples of $3 \mu \mathrm{g}$ were digested to completion with the relevant restriction endonuclease and the resulting fragments were separated according to molecular weight by electrophoresis overnight in a $0.9 \%$ agarose gel at $40 \mathrm{~V}$. Southern blots onto $\mathrm{Hy}-\mathrm{Bond}-\mathrm{N}$ (Amersham) filters were performed, and the various probes were then hybridised to the filters.

Southern blotting was performed as described by Southern, ${ }^{17}$ with certain modifications. The membrane was presoaked in $10 \times \mathrm{SSC}$ before blotting, and DNA transfer was carried out in $10 \times$ SSC overnight. After blotting, filters were irradiated with UV light at $306 \mathrm{~nm}$ for five minutes. Prehybridisation was at $65^{\circ} \mathrm{C}$ for two to three hours in $15 \mathrm{ml} 6$ $\times$ SSC, $5 \times$ Denhardt's, $0.5 \%$ SDS, and $7 \%$ dextran sulphate.

\section{DNA PROBES}

The DNA probes used in this study were radiolabelled by nick translation using a commercial kit (Amersham). Unincorporated nucleotides were separated in a Sephadex G-50 column and $2.5 \mathrm{mg}$ herring sperm DNA was added to yield a final concentration of $20 \mu \mathrm{g} / \mathrm{ml}$.

The solution was boiled for five minutes and was then added to the prehybridisation mix. Hybridisation was performed overnight at $65^{\circ} \mathrm{C}$. Posthybridisation washes were at the same temperature in $2 \times \mathrm{SSC}$ and $0 \cdot 1 \% \mathrm{SDS}$ for 10 to 20 minutes. The stringency of washing was increased by incubation in decreasing concentrations of SSC $(1 \times \operatorname{SSC}$ to $0 \cdot 1 \times$ SSC) for five to 15 minutes, depending upon the probe and the strength of the radioactivity signal. Autoradiography onto Fuji $x$-ray film was performed at $-70^{\circ} \mathrm{C}$ with an intensifying screen for two to seven days.

GLYCEROL ASSAYS

Glycerol levels in serum and urine were estimated by a modification of Sigma Triglyceride Kit No 320-UV. Glycerol levels were estimated enzymatically in a linked assay by following its conversion to glycerol-1-phosphate and ADP upon incubation with glycerol kinase and ATP. Pyruvate kinase catalyses the conversion of ADP and phosphoenol pyruvate to pyruvate and ATP. The subsequent reduction of pyruvate to lactate by lactate dehydrogenase and NADH was followed spectrophotometrically at $340 \mathrm{~nm}$ in a Kontron Uvicon 820 spectrophotometer.

Thin layer chromotography of urine was used to show the gross glyceroluria in our patient. Desalted urine was extracted with chloroform:methanol 2:1 (v/v) and applied onto a cellulose TLC plate and then chromatographed in butanol:pyridine: $0.1 \mathrm{~mol} / \mathrm{l}$ 
$\mathrm{HCl} 5: 4: 1$. Glycerol was visualised by spraying with alcoholic silver nitrate. The technique of glycerol kinase assay has been described by Dunger et al.

\section{Results}

Case 1 was already known to have adrenal hypoplasia and mental retardation and the investigations established the presence of a chromosomal deletion. Cytogenetic analysis of a number of prometaphase and metaphase cells by direct microscopical examination and by photography showed an interstitial deletion of the segment $\mathrm{p} 21 \cdot 1 \rightarrow \mathrm{p} 22 \cdot 11$ of the $\mathrm{X}$ chromosome in the proband $(\mathrm{JH})$ (fig 1). The deletion was also observed in one of the two maternal X chromosomes (fig 2). Direct measurement of enlarged photographic prints of eight cells from the heterozygote showed that the total length of the deleted $X$ was $9 \%( \pm 3 \%)$ less than the normal $\mathrm{X}$ chromosome, while there was no difference in the mean lengths of the $\mathrm{X}$ long arms (fig 3 ).
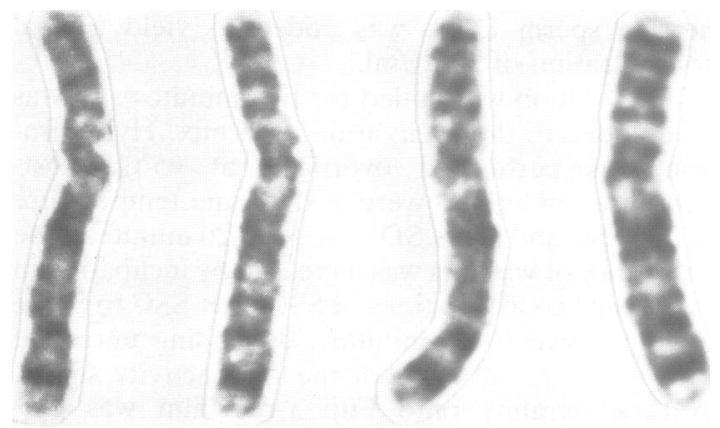

FIG 1 X chromosomes from four cells of case 1.
BrdU incorporation studies showed that the deleted $\mathrm{X}$ was late replicating in 31 out of $33(94 \%)$ cells examined in the heterozygote (fig 4).

The X chromosomes of the proband's sister $(\mathrm{KH})$ and the maternal grandmother were normal. The deletion, therefore, was a new mutation in the proband's mother.

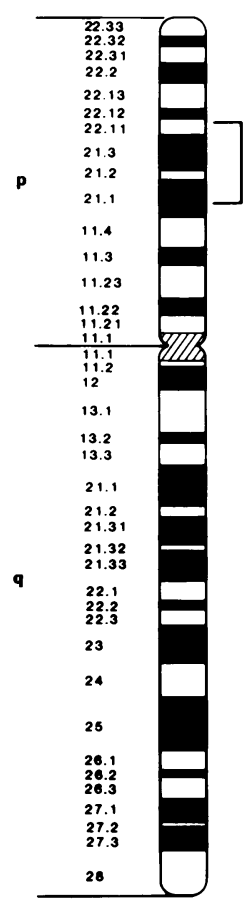

FIG 3 Diagram of the $X$ chromosome indicating the segment deleted in case 1 .
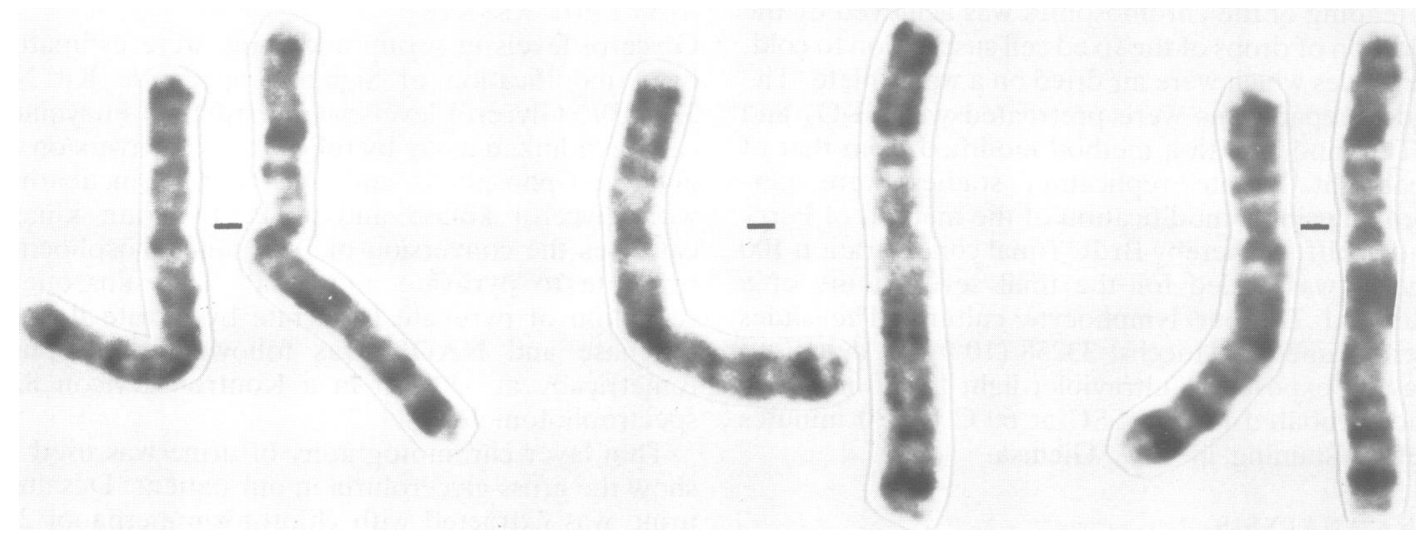

FIG $2 X$ chromosomes from three cells of the mother of case 1. 


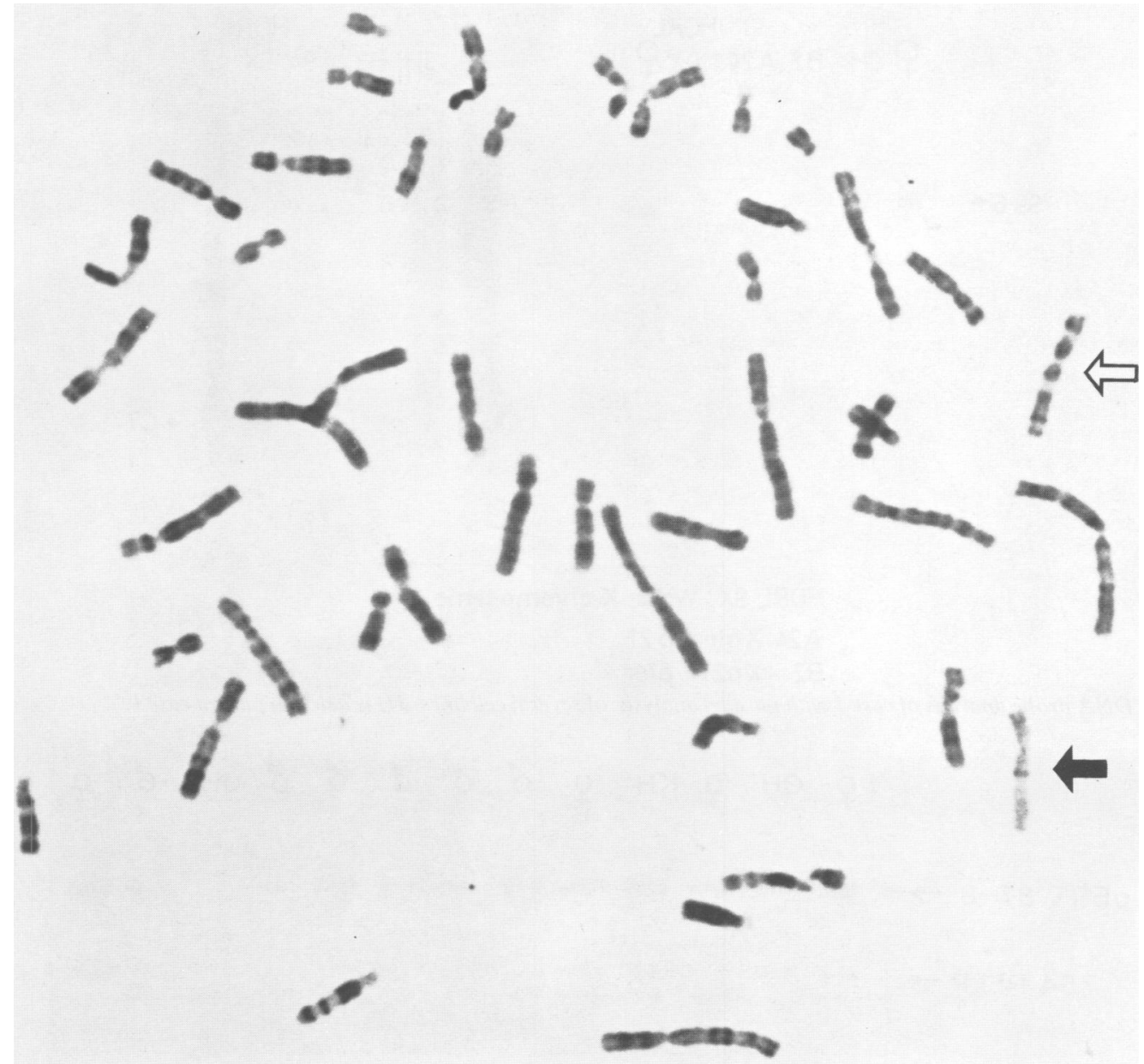

FIG 4 BrdU induced $R$ banding in a cell from the mother of case 1 showing the late replicating deleted $X$ chromosome (black arrow) compared with the normal X (white arrow).

Analysis of DNA from case 1 confirms the presence of a deletion, since probes $754, \mathrm{XJ} 1-1$, pERT87-1, 87-8, and 87-15, and C7 all fail to hybridise to his DNA (fig 5). That his sister has two normal $\mathrm{X}$ chromosomes is confirmed by her DNA showing two alleles for the probe 754 (fig 6). Urine and serum from case 1 were found to contain raised concentrations of glycerol, as found in other patients with GK deficiency. His serum level was $5 \cdot 3$ and his urine level $300 \mathrm{mmol} / \mathrm{l}$. His fibroblast GK level was found to be reduced (table 3 ).

Prompted by this case, we have also screened 20 other boys with DMD for glyceroluria (table 3 ), in addition to the surviving DMD males with a molecular deletion. This has revealed one other case with raised levels of glycerol in his urine, but whose serum glycerol level was normal. This boy (case 2) had his urine glycerol assayed on three separate occasions, the results being raised on each occasion, though not to the same extent as case 1 . His urinary glycerol levels were 9.9, 3.2, and 10 $\mathrm{mmol} / \mathrm{l}$, the mean of $7.7 \mathrm{mmol} / \mathrm{l}$ being nearly 40 times the upper limit of the normal range $(\leqslant 0.2$ $\mathrm{mmol} / \mathrm{l})$, compared to case 1 whose glyceroluria is 1500 times the upper limit of normal. It is interesting that the glycerol kinase level assayed in skin fibroblasts taken from case 2 were normal or high. Cytogenetic analysis showed no abnormality of the $\mathrm{X}$ chromosome of case 2 and no molecular deletion has been identified. 


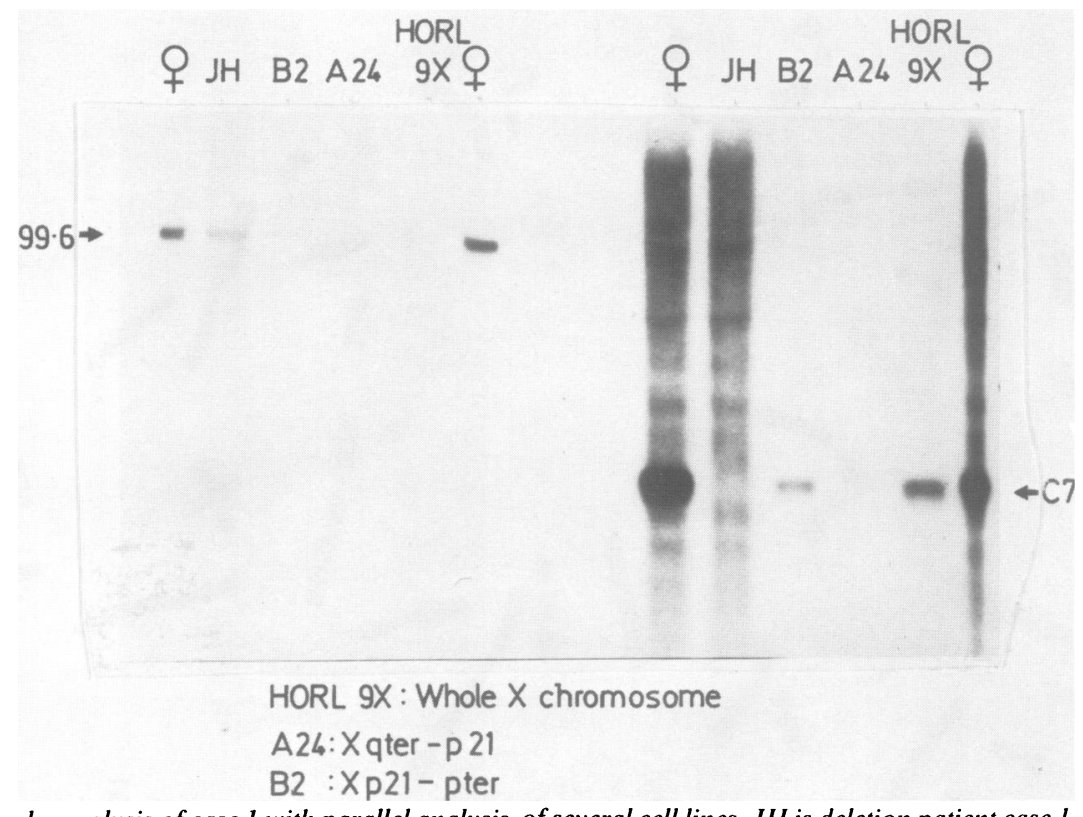

FIG 5 DNA probe analysis of case 1 with parallel analysis of several cell lines. JH is deletion patient case 1.

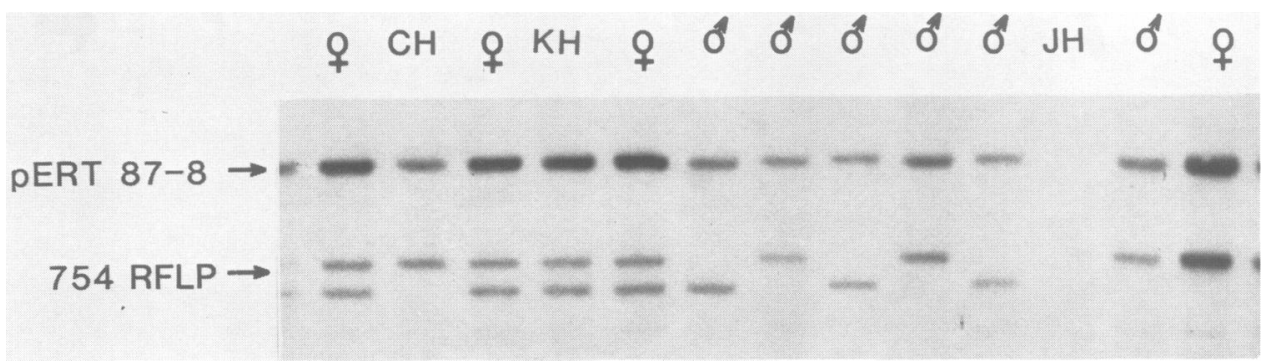

FIG 6 DNA probe analysis of the family of deletion patient $\mathrm{JH}$ (case 1). $\mathrm{CH}$ is his mother and $\mathrm{KH}$ is his sister.

TABLE 3 Comparison of cases with and without deletions (see paper by Thomas et al on page 509 of this issue).

\begin{tabular}{|c|c|c|c|c|}
\hline & $\begin{array}{l}\text { Case } \\
\text { I }\end{array}$ & $\begin{array}{l}\text { Case } \\
2\end{array}$ & $\begin{array}{l}\text { Molecular } \\
\text { deletion } \\
\text { cases }\end{array}$ & $\begin{array}{l}\text { Other cases } \\
\text { without known } \\
\text { deletion }\end{array}$ \\
\hline Cytogenetic deletion & Yes & No & No (8 families) & Not tested \\
\hline Molecular deletions & Yes & No & Yes & No \\
\hline Familial case & No & No & 4 of 8 families & 53 of 109 \\
\hline $\begin{array}{l}\text { Urine glycerol } \\
(\leqslant 0 \cdot 2 \mathrm{mmol} / \mathrm{l})\end{array}$ & 300 & $7 \cdot 7$ & Normal (6 cases) & Normal (19) \\
\hline $\begin{array}{l}\text { Serum glycerol } \\
(\leqslant 0.2 \mathrm{mmol} / \mathrm{l})\end{array}$ & $5 \cdot 3$ & $0 \cdot 15$ & Not tested & Not tested \\
\hline Glycerol kinase (4-29 units) & $2 \cdot 5$ & $38 \cdot 6$ & Not tested & Not tested \\
\hline Adrenal hypoplasia & Yes & No & No & No \\
\hline $\begin{array}{l}\text { Mental retardation } \\
\text { (where known) }\end{array}$ & Yes & No & 4 of $9(44 \%)$ & 14 of $58(24 \%)$ \\
\hline
\end{tabular}

NB A case is considered familial when there has been more than one affected male in the family.

Mental retardation is taken to mean an IQ level of less than 70 on formal testing or estimated by level of functioning.

Glycerol kinase: units are nmol glycerol phosphate/mg protein/h.
Nine other boys with DMD and a molecular deletion revealed by probes pERT87 or XJ1-1 or both have been identified from eight families during the course of studies in our department. Cytogenetic analysis has been performed on lymphocyte cultures from five of the boys and on the mother of the other four boys. Three of the mothers are obligatory carriers of DMD, while the mother of the other case (where the boy has died) has a probability of being a carrier from pedigree and serum creatine kinase data of $18 \%$. Direct microscopical examination and photography of several cells from these cases showed no abnormality of the $\mathrm{X}$ chromosome at a resolution up to 850 haploid bands ${ }^{18}$ (fig 7). In addition, six surviving boys from five families had urine samples screened for glyceroluria as detailed above, but raised levels were not found. The clinical 


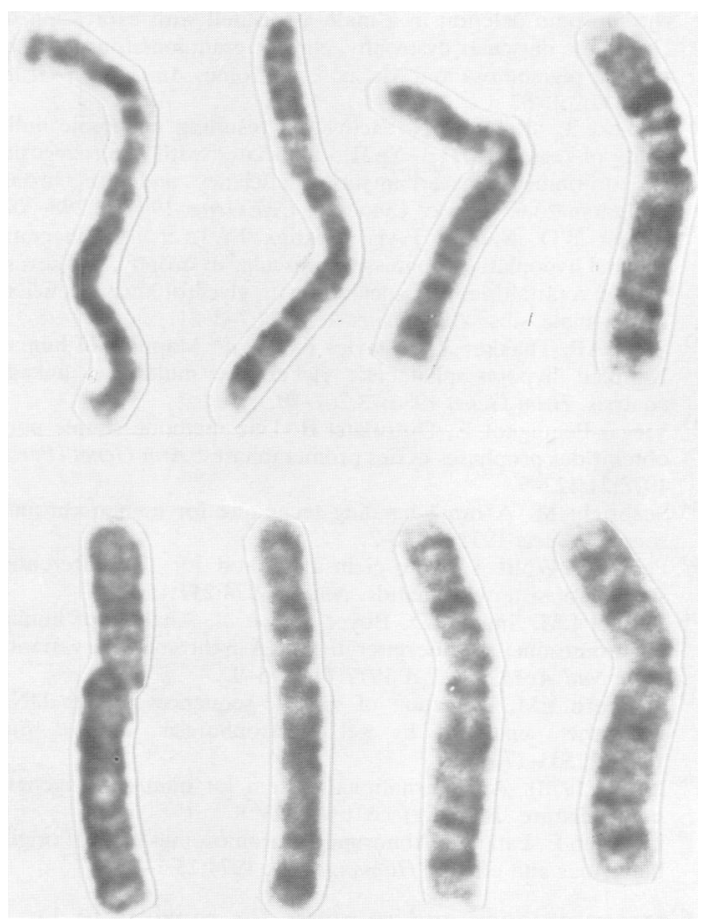

FIG $7 X$ chromosomes from two cases with a molecular deletion of $p E R T 87$, but no detectable cytogenetic deletion.

features of the cases where cytogenetic analysis has been performed are compared with other cases in table 3 (and see Thomas et al on page 509 of this issue).

\section{Discussion}

Investigation of the family of case 1 has proved valuable in both practical and theoretical terms. It has been of direct help to the family in that the need for a chorionic villus biopsy, already booked, was averted because the patient's sister was shown not to carry the $\mathrm{X}$ chromosome deletion found in association with DMD in her brother. It also provides further evidence that the gene loci for DMD, GK, and $\mathrm{AH}$ all map within $\mathrm{Xp} 21 \cdot 1 \rightarrow \mathrm{p} 22 \cdot 11$, together with the DNA probes 754, XJ1-1, pERT87, and C7. Conversely, it is unlikely that the locus for other severe $\mathrm{X}$ linked diseases will map to this region, except perhaps for chronic granulomatous disease. ${ }^{9}$ A skin fibroblast cell line has been established from the patient, which is available to interested research workers.

As is almost universally the case in unbalanced structural rearrangements of the $\mathrm{X}$ chromosome, ${ }^{19}$ the interstitial deletion $X$ was preferentially inactivated in the phenotypically normal mother of case 1 . This is in contrast to the random inactivation pattern that was observed with a deletion of similar length involving the $\mathrm{Xp} 21$ region in a woman reported by Francke ${ }_{10}^{10}$ who exhibited mild mental retardation, partial ornithine transcarbamylase deficiency, and heterozygosity for chronic granulomatous disease. The reason for this disparity, in the apparent absence of the locus for these severe $X$ linked diseases from the deleted segment in our case 1 , is unclear.

Case 2, with DMD and a moderate glyceroluria and without any detected deletion, presents a less straightforward picture. This patient has none of the associated problems found in addition to DMD in case 1 and some of the previously reported cases of complex DMD. In particular, he is mentally normal, his diurnal cortisol rhythm and his response to a short Synacthen test are both normal, and he does not suffer clinically from any immune deficiency. The glycerol kinase results are interesting. The level was expected to be reduced in case 1 and low/normal in case 2 . To find a high/normal level in case 2 was unexpected and is unexplained. Examination of new cases of DMD for glyceroluria could be of clinical as well as theoretical interest, since this may serve as a marker for susceptibility to adrenal failure.

Interstitial deletions of the $\mathrm{X}$ chromosome are uncommon, even in those with $\mathrm{X}$ linked diseases such as DMD, but the information gained when they are found is both of clinical application and of research interest. Our practice is to undertake cytogenetic analysis when a boy with DMD suffers from mental retardation or any additional problem that could be $\mathrm{X}$ linked, when such a boy is found to carry a deletion detected by DNA analysis, or when excess glycerol is found in his urine. In all these situations, cytogenetic investigation could be informative, although we do not yet know how often this will prove to be the case. No anomaly was found in the nine cases where cytogenetic analysis was performed because of a molecular deletion.

We would like to thank Dr Prenton of the Royal Hospital, Chesterfield for referring this family, and Dr MacConnachie and Mr Mohammed of the same hospital for their assistance in the investigation of their patient. We thank Dr G Hoskings of The Childrens' Hospital, Sheffield, for performing a skin and muscle biopsy, Dr N Matthews, of the Department of Immunology at the University Hospital of Wales, for the immune function tests, and $\mathrm{Dr} R$ Walker, of the Tenovus Institute at the University 
Hospital of Wales, for the salivary and serum cortisol assays. We would also like to thank Dr J R Sibert for permission to study patient 2 . This work was supported by the Muscular Dystrophy Group of Great Britain and The Muscular Dystrophy Association of America.

\section{References}

1 Guggenheim MA, McCabe ERB, Roig M, et al. Glycerol kinase deficiency with neuromuscular, skeletal and adrenal abnormalities. Ann Neurol 1980;7:441-9.

2 Bartley JA, Patil S, Davenport S, et al. Duchenne muscular dystrophy, glycerol kinase deficiency, and adrenal insufficiency associated with $\mathrm{Xp} 21$ interstitial deletion. $J$ Pediatr 1986;108:189-92.

${ }^{3}$ Saito F, Goto J, Kakinuma H, et al. Inherited Xp21 deletion in a boy with complex glycerol kinase deficiency syndrome. Clin Genet 1986;29:92-3.

${ }^{4}$ Wieringa B, Hustinx T, Scheres J, et al. Glycerol kinase deficiency syndrome explained as $\mathrm{X}$-chromosomal deletion. Cytogenet Cell Genet 1986;40:777A.

5 Dunger DB, Pembrey M, Pearson P, et al. Deletion on the $\mathrm{X}$ chromosome detected by direct DNA analysis in one of two unrelated boys with glycerol kinase deficiency, adrenal hypoplasia, and Duchenne muscular dystrophy. Lancet 1986;i:585-7.

6 Wilcox DE, Cooke A, Colgan J, et al. Duchenne muscular dystrophy due to familial Xp21 deletion detectable by DNA analysis and flow cytometry. Hum Genet 1986;73:175-80.

7 Patil SR, Bartley JA, Murray JC, et al. X-linked glycerol kinase, adrenal hypoplasia and myopathy maps at Xp21. Cytogenet Cell Genet 1986;40:720-1A.

${ }^{8}$ Hammond J, Howard NJ, Brookwell R, et al. Proposed assignment of loci for $\mathrm{X}$-linked adrenal hypoplasia and glycerol kinase genes. Lancet $1985 ; \mathrm{i}: 54$.

${ }^{9}$ Francke U, Ochs HD, de Martinville B, et al. A minor Xp21 chromosome deletion in a male associated with expression of Duchenne muscular dystrophy, chronic granulomatous disease, retinitis pigmentosa and McLeod syndrome. Am J Hum Genet 1985;37:250-67.

${ }^{10}$ Francke U. Random X-inactivation resulting in mosaic nullisomy of region $\mathrm{Xp} 21 \cdot 1-\mathrm{Xp} 21 \cdot 3$ associated with heterozygosity for ornithine transcarbamylase deficiency and for chronic granulomatous disease. Cytogenet Cell Genet 1984;38:298-307.

" Renier WO, Nabben FAE, Hustinx TWJ, et al. Congenital adrenal hypoplasia, progressive muscular dystrophy, and severe mental retardation, in association with glycerol kinase deficiency, in male sibs. Clin Genet 1983;24:243-51.

12 Read AP, Thakker RV, Davies KE, et al. Mapping of human $\mathrm{X}$-linked hypophosphataemic rickets by multilocus linkage analysis. Hum Genet 1986;73:267-70.

13 Viegas-Pequignot E, Dutrillaux B. Une methode simple pour obtenir des prophases et des prometaphases. Ann Genet (Paris) 1978;21:122-5.

14 Seabright M. A rapid banding technique for human chromosomes. Lancet 1971;ii:971-2.

15 Perry P, Wolff S. New giemsa method for the differential staining of sister chromatids. Nature 1974;251:156-8.

${ }^{16}$ Kunkel LM, Smith KD, Boyer SH, et al. Analysis of human Y-chromosome-specific reiterated DNA in chromosome variants. Proc Natl Acad Sci USA 1977;74:1245-9.

17 Southern EM. Detection of specific sequences among DNA fragments separated by gel electrophoresis. J Mol Biol 1975;98:503-17.

${ }^{18}$ ISCN (1978). An international system for human cytogenetic nomenclature. Birth Defects 1978;XIV:8.

19 Therman E, Patau K. Abnormal X chromosomes in man: origin, behaviour and effects. Humangenetik 1974;25:1-16.

Correspondence and requests for reprints to Dr Clarke, Section of Medical Genetics, University of Wales College of Medicine, Heath Park, Cardiff. CF4 4XN 